\title{
Society empowerment by sustaining volunteerism culture
}

Mir Sayed Shah Danish ${ }^{1}$, Tomonobu Senjyu², Seyedeh Maryam Tayarani ${ }^{3}$, Michell Ann Julieth Marasigan ${ }^{4}$, Hameedullah Zaheb $^{2}$, Alexandra Gebarowska ${ }^{3}$, Maria Luisa Grilli ${ }^{5}$

${ }^{1}$ Strategic Research Project Center, University of the Ryukyus, 1 Senbaru 9030213, Japan

${ }^{2}$ Department of Electrical and Electronics Engineering, Faculty of Engineering, University of the Ryukyus, Okinawa 903-0213, Japan

${ }^{3}$ Department of Academic Affairs, Research and Education Promotion Association (REPA), Okinawa 900-0015, Japan

${ }^{4}$ Liaison Office, Research and Education Promotion Association (REPA), Okinawa 900-0015, Japan

${ }^{5}$ Department of Energy Technologies and Renewable Sources, Italian National Agency for New Technologies, Energy and Sustainable Economic Development (ENEA), Casaccia Research Centre, Via Anguillarese 301, 00123 Rome, Italy

Article

Open Access

Published

\section{Keywords}

- Volunteer, young volunteer

- Volunteer role

- Volunteering benefits

- Volunteerism nature

- Volunteerism

- Volunteer types

- Volunteer ethics

- Volunteer traits

\section{ABSTRACT}

This study interrogates the role of volunteers in society empowerment to enable students with a broad view of volunteerism as a first action. This study aims to encourage volunteer research, education, and social activities at the undergraduate and graduate students' levels. At first sight, significant workforce needs exist in educational research and studies, while only a small percentage of students volunteer their services. Consequently, many students miss the opportunity to give back to the community and excel in their academic and career assets in the long run. The analysis exposed that students are the first beneficially in unique ways if they volunteer in research and education. It is also observed that research immensely impacts learning, and knowledge positively influences society. Therefore, by implication, volunteer activities in research and education will benefit young volunteers and communities. Besides, volunteer opportunities are readily available to students. Also, conducting volunteer activities has been impactful on the overall performance rating. A volunteer should train and learn best practices and behavior. It will promote educational research, student success and improve livelihood in the community. In conclusion, this study reveals that volunteering in the field of education and research is critically important for students to participate in volunteer activities.

Received: July 20, 2021; Revised: August 11, 2021; Accepted: August 12, 2021; Published: August 20, 2021 (c)2021 REPA. All rights reserved.

\section{Introduction}

With the exponential growth of population and rapid change of social and economic infrastructure, most governments fail exclusively to meet all citizens' needs. Thus, the emergency of the voluntary sector has somewhat filled this gap, which is left by the government [1]. Several governments have promoted volunteering, and students remain an immense contribution. A young volunteer who participates in social actions during their studies develops essential skills for employment and adulthood. However, not many students consider it paramount. Whereas others face several barriers, others have a negative perception or hold stereotypical views. For instance, in [2], authors have raised concerns about the decline in US volunteerism. University students will benefit a lot if they fit volunteering in research and education in their schedule. If you are a student, this paper will give you sufficient reasons to offer voluntary services in research and education. It highlights reasons to volunteer, the benefits, mentions volunteer opportunities, and recommended conduct during your work. Moreover, this study interrogates the relationship between a volunteer, sponsor organizations, and salaried staff. Also, it looks into types of volunteers and the future of research and education from volunteerism perspectives. There is a need for an awareness mechanism for voluntary contributors in the field of research and education, i.e., Many students are likely to volunteer, but most of them do not come with specific aims for being a volunteer and the future direction for volunteering. The investigation leads to the innovation of new ideas and techniques to address critical needs on campus and community levels. Therefore, this study seeks to create awareness among students and draw a roadmap for becoming an active volunteer by all means. So, more students who become aware of volunteer activities and their importance efficiently empower communities [3].

\section{Literature review}

This section review literature related to volunteers' activities. It gives an overview of different dimensions of viewing the subject to provide a more profound comprehension of the volunteerism nature. In [4] author recognizes inadequacy of training programs for youth about types, roles, purpose, and requirements for volunteering. In which, claimed that formal education curriculums need to be used to train young professionals and community workers to understand their position, and enable and facilitate volunteers; their role does not substitute for volunteerism. As a result, this study asserts the need for volunteer training programs to achieve these outcomes: In [5] author sought and asserted that ownership of all community development efforts lies with local volunteers. This study states that volunteers shape communication channels, facilitate inter-class and other divides 
interactions, and connect the local population. Therefore, volunteers must understand their role, obtain training, and put their knowledge and skills into practice. This kind of effort is what leads to the emergency response of a community. According to [6], three areas relate to trust-building for volunteers. The first one is moral obligations of volunteer leadership. They should act given the duty of care, loyalty, and obedience by acting in good faith and compliance with the laid down rules and policies and keeping the organization's secrecy. Secondly, the stewardship of the organization plays a vital role. Both volunteers and paid staff should seek to achieve their organization's overall objectives. In doing so, they must maintain reputation for their institution's integrity, follow legal procedures, and do not overstep their mandate.

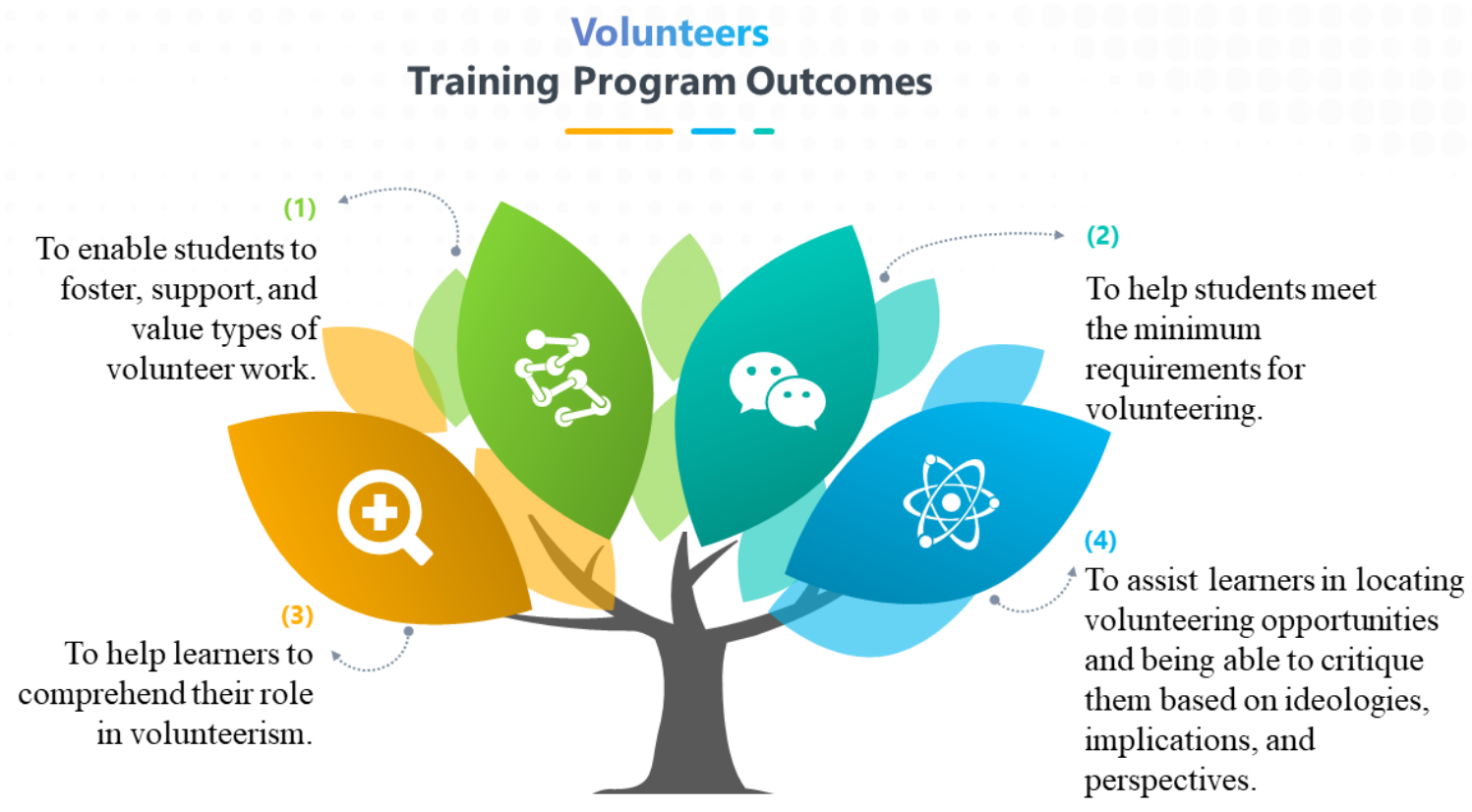

Figure 1. Volunteers' training program outcomes.

\section{Volunteers \\ Category}

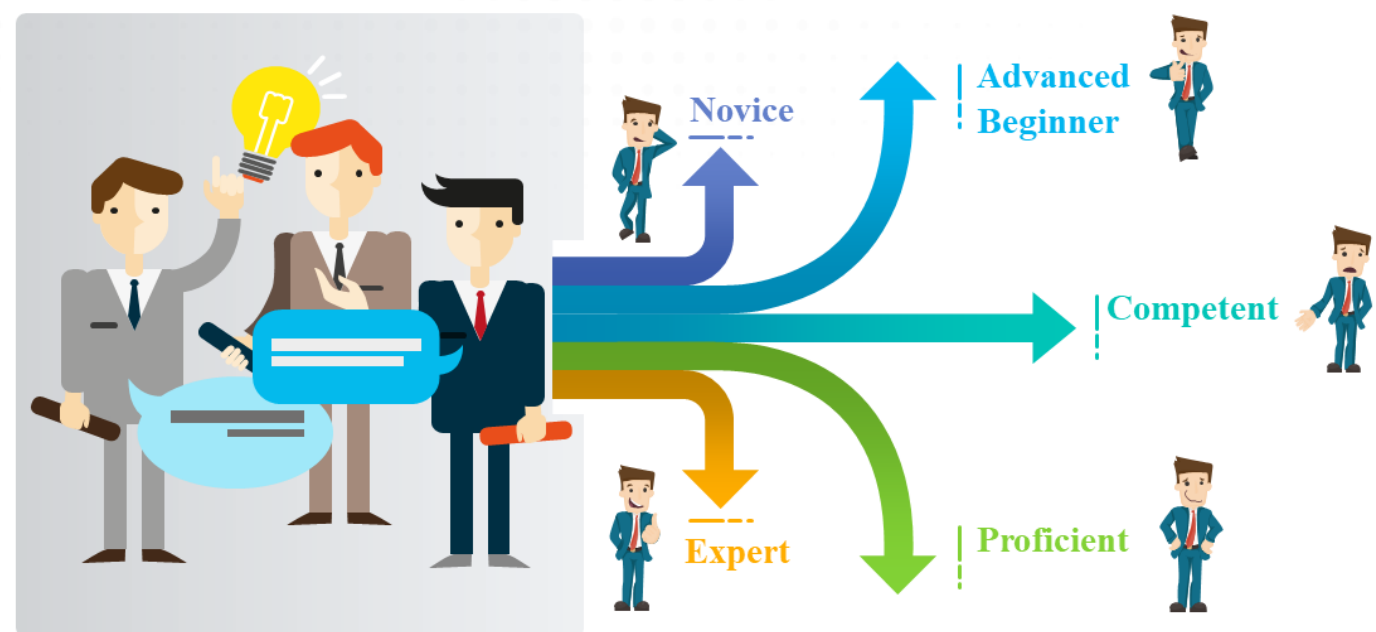

Figure 2. Volunteers category. 
Research [7] reveals a gap between participatory citizenship and internet behavior. There is less participation in humanitarian and social sectors. It suggests that an online platform is best suited for activism. If it is well utilized, many students will be reached, and more participation will follow.

According to [8], the below categorization determines the degree of supporting a volunteer's needs. For a student volunteering for the first time, self-evaluation is essential to decide extent of support needed.

Table 1: Categories of volunteers [8].

\begin{tabular}{|c|c|c|c|}
\hline No. & Category & Volunteer Trait & $\begin{array}{l}\text { Support Re- } \\
\text { quirements }\end{array}$ \\
\hline 1 & Novice & $\begin{array}{l}\text { An unskilled/inexperienced vol- } \\
\text { unteer. }\end{array}$ & $\begin{array}{l}\text { Intensive } \\
\text { support }\end{array}$ \\
\hline 2 & $\begin{array}{l}\text { Advanced } \\
\text { beginner }\end{array}$ & $\begin{array}{l}\text { They possess some skills and } \\
\text { knowledge in limited areas. }\end{array}$ & $\begin{array}{l}\text { Medium Sup- } \\
\text { port }\end{array}$ \\
\hline 3 & Competent & $\begin{array}{l}\text { More skilled, able to plan con- } \\
\text { sciously, application of longer- } \\
\text { term goals. }\end{array}$ & $\begin{array}{l}\text { Minimal Sup- } \\
\text { port }\end{array}$ \\
\hline 4 & Proficient & $\begin{array}{l}\text { Quickly able to act as a significant } \\
\text { co-worker, showing sensitivity } \\
\text { and skill. }\end{array}$ & Partnership \\
\hline 5 & Expert & $\begin{array}{l}\text { They have high levels of profi- } \\
\text { ciency, both skills and knowledge } \\
\text { of value to the agency. }\end{array}$ & $\begin{array}{l}\text { Reciprocal } \\
\text { support and } \\
\text { induction }\end{array}$ \\
\hline
\end{tabular}

\section{Advantages of volunteering}

In [9], many advantages of volunteering at on campus level is highlighted; for instance, volunteering activities will:

- improve students resume

- attract employers to prefer candidates who care about the community
- make volunteering habit and potential route to employment

- count as an experience, and employers will be hesitant to hire candidates without experience be the best means of gaining and sharing knowledge

- offers an opportunity to develop skills and try something new

- help students create a professional network. Most students would volunteer in a field or niche of their interest or related to their academic background. Consequently, they network with various professionals in the area and learn about new jobs or internship opportunities.

- $\quad$ get free advice and job referrals from their counterparts and professionals.

In [10] author states that volunteering helps students improve their grades. Students who volunteer are most likely to be focused on their academic performances. Also, the volunteering positions boost the student's learning potential.

Volunteers have fantastic health benefits. They seldom get ill or experience depression and have a lower mortality rate. The most successful students often volunteer to give back to the community and enjoy improved health [11]. Besides being a rewarding experience, volunteering makes scholars happier and better people in the long run. Many more volunteering benefits exist, and below are how students can benefit if they serve the community.

Western Connecticut State University [12] findings state that volunteering helps students build self-esteem and confidence. Serving others in the community creates a sense of accomplishment, pride, and identity. The affirmative and better feel of self positively impacts the view of self and future goals.

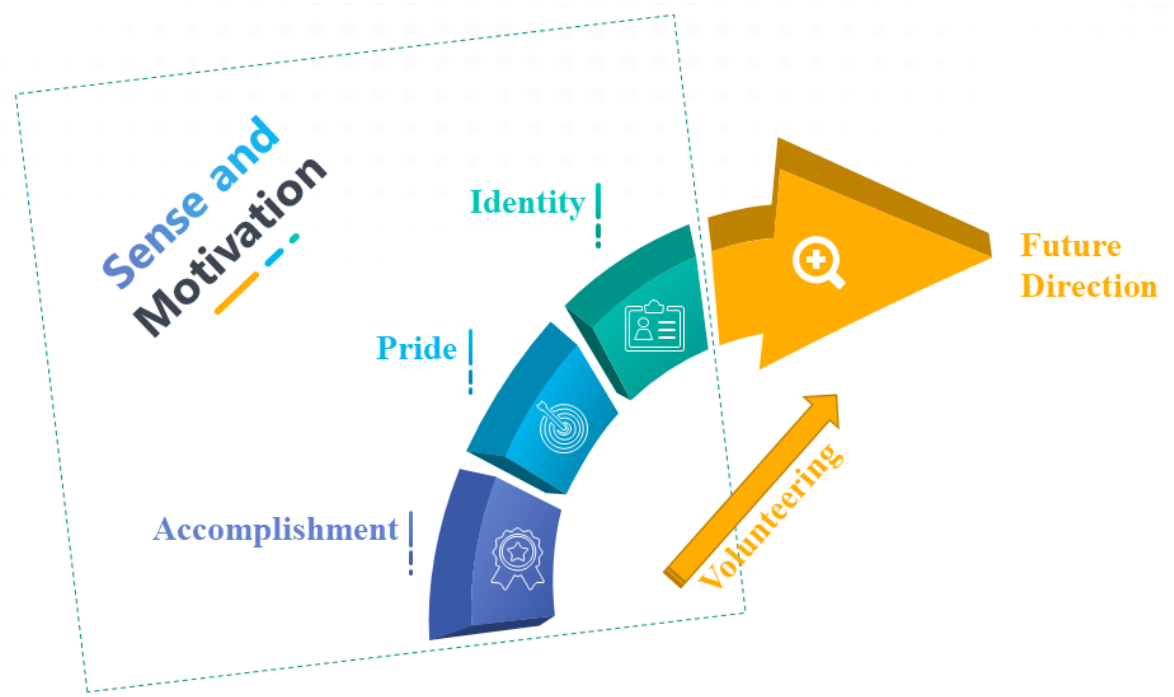

Figure 3. Volunteering leads toward self-esteem and confidence. 
Overall, when and how a volunteer activity can be demonstrated with some constraints?

1- It consumes a lot of time: If one is not diligent, they can easily accept more tasks than they can handle. For students who work part-time or have families, volunteering can negatively impact other areas in life. However, most volunteer work is flexible and busy students can plan and schedule a few of the available hours for it. So, it is a matter of plan and organization.

2- It lacks monetary compensation: Despite being emotionally rewarding, a young volunteer may spend a lot of money without payback. Also, time spent in works may lead to fewer income-generating activities. However, in view of considering it a setback, experience can quickly turn into a job opportunity. Besides, it leads to more knowledge, experience, and networking that quantifies a volunteer for the highest paying.

3- It can lead to personality conflicts: Since sponsor organizations accept volunteers from all walks of life, meeting a person with a negative attitude or an annoying character is possible. It can be detracting and stressful, but you can build a strong personality and stay focused on your goal.

4- It can be emotionally and physically tiring and frustrating: It may involve a lot of manual work. It can also be primarily frustrating when things do not work out or received no recognition for a good outcome.

\section{How to deal with barriers to volunteering}

According to [13], students who do not experience volunteering, if compared to the opportunities they miss, they will be amazed. Almost all the impediments are manageable and cannot impede a willing heart.

The first thing is to interrogate what volunteering entails, and this study deals with the subject. People can make time for what they genuinely believe, but in the worst-case scenario, a student can turn their hobbies into a sponsorship opportunity. Some students hardly know any group that would need their help. Finding a perfect target to donate time can be daunting. However, in this research essay, the field of research and education is the best starting point for students.

Students who undervalue volunteering to ask, "What is the point of volunteering?" To overcome such stereotypical views, a student needs a thorough comprehension of volunteering benefits to self and society.

Other students find it challenging to find a role that fits their expertise or interests. It is essential to point out that volunteers often come from all walks of life, and any student will find a fit. Besides, volunteer managers have the skill to find a way of working with any talent and interests.

\section{Volunteering opportunities for students}

There is no question that volunteering benefits are excellent for students. This section will highlight some of the opportunities available for students to explore. The high paybacks of volunteering are sufficient reasons to schedule it in a student's busy schedule. According to [14], there is always an opportunity for a student to offer services in the community. Below is a list of some of them.

1- Charitable organizations: Perhaps this is one of the most obvious options. The organizations have a considerable workload and are always looking for an extra hand. Students can select an organization of their interest within their locality to offer their voluntary services. Check out websites for international and local organizations operating within your area and make applications.

2- Campus events: Universities are hubs of activities, from talk shows, fundraisers, and career exhibitions to job fairs and departmental shows. Talk of alumni events and parties, you can volunteer your services in any of those.

3- Youth organizations in the community: In most cities, you will find youth and scout volunteering programs. Besides, some of these groups offer free mentorship services to volunteers. Also, you can volunteer your services in local worship places.

4- Offer free tutoring services: As a student, you will hopefully receive in-depth knowledge in your field of interest. The community offers fantastic opportunities to share your experience. For instance, elementary schools and adult literacy programs would need your services. Besides, someone could be looking for a private tutor.

5- Alternative spring break programs: Some universities have spring break programs, but you can join some independent sponsored spring break programs if yours does not.

Whereas there are many options, a young volunteer on campus has a duty to volunteer in research and education. Volunteerism is not a new phenomenon and can be traced in many parts of the world. For instance, during the precolonial period in Africa, voluntary activities were associated with a virtuous citizen in Tanganyika. However, the concept existed before colonization as a concept of ethics and service. In the 1940s, it was viewed as a means of providing services that the governments could not afford [15]. The concept of volunteerism has evolved, and the best area for the current students is in research and education. The next section focuses on volunteer activities in research and education. The behavior of third parties through which a student should volunteer to impact the overall outcome. As a result, some diligence is needed in selecting the organization to facilitate your volunteer activities. 


\section{Importance of research to education}

Research is critical in many educational fields. This paper looks at the importance of research in education. For most courses, research is mandatory, but more than that, any student would prefer to volunteer in research and education. Below is a list of notable roles and volunteering benefits that study offers in education [16].

1- Research is a systematic analysis that gives deeper comprehension: The objectives of the study are often clearly defined, and the process is determined and controlled. Consequently, it provides an opportunity for a student to have more in-depth insights into the subjects.

2- Research leads to excellent observations: In this field of education, research interrogates many explanations, data, facts, and figures to conclude. It helps students learn how to process complex information to arrive at a solution.

3- It helps students to predict outcomes, interrogate theories and principles: Using research observations, hypotheses, and queries, a student can validate principles and methods and predict the product based on the analysis.

4- Research complements the study and helps retain memory of areas studied: It initiates action, for instance, data collection, processing, and decision making. Whenever the research findings are consistent with the study done, it interests and settles the ideas well in mental faculties.

5- Being a length process, research in education develops patience. No one would wish to repeat the process, and therefore it is often done precisely and accurately. Moreover, it enhances the student's knowledge.

\section{The conduct of a volunteer}

Students offering voluntary services have an opportunity to demonstrate skills and hire their knowledge. Conduct during service impacts the professional future making a deeper comprehension of the volunteerism nature worth studying. To have a positive effect and a successful volunteer experience, you need to learn certain practices [17]:

1- Be punctual and handle tasks on time.

2- Complete relevant training.

3- Follow directions, guidelines, and rules.

4- Develop an optimistic and open-minded attitude in different circumstances.

5- Be committed and deliver your promises.

6- Be polite and have patience during tough times.

7- Keep the secret of the organization you work with and respect the privacy of your colleagues.

8- Be thoughtful and provide positive feedback.

9- Be flexible in accepting tasks outside your profession.

10- Continuously pursue ways you can improve the quality of your services.

Also, there are some advice to be avoided:

1- Do not be intrusive or force help to people who are not keen on your services.

2- Do not shy away from asking questions whenever you need clarification.

3- Do not fear making mistakes as you learn.

4- Do not worry about contacting your supervisor when you are likely to be late or miss an appointment.

5- Do not forget to keep track of your working hours.

\section{The influence of third-party organizations}

Volunteer involves a donation of resources, time, benefiting others, and is often through an intermediary that can be a university or an organization. The behavior and goals of these third-party organizations impact the success of the volunteer and program. Besides, when the organization's specific objectives and respect exist between paid employees and volunteers, there will be excellent service experience. Lastly, the organizational strategies of these organizations play a crucial role. For instance, volunteer recruitment, training, and retention would impact the quality of services. 


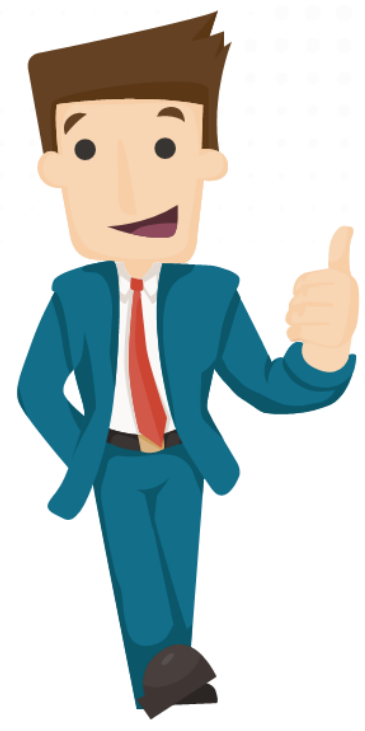

\section{Requirement for An Efficient and Satisfied Volunteer}

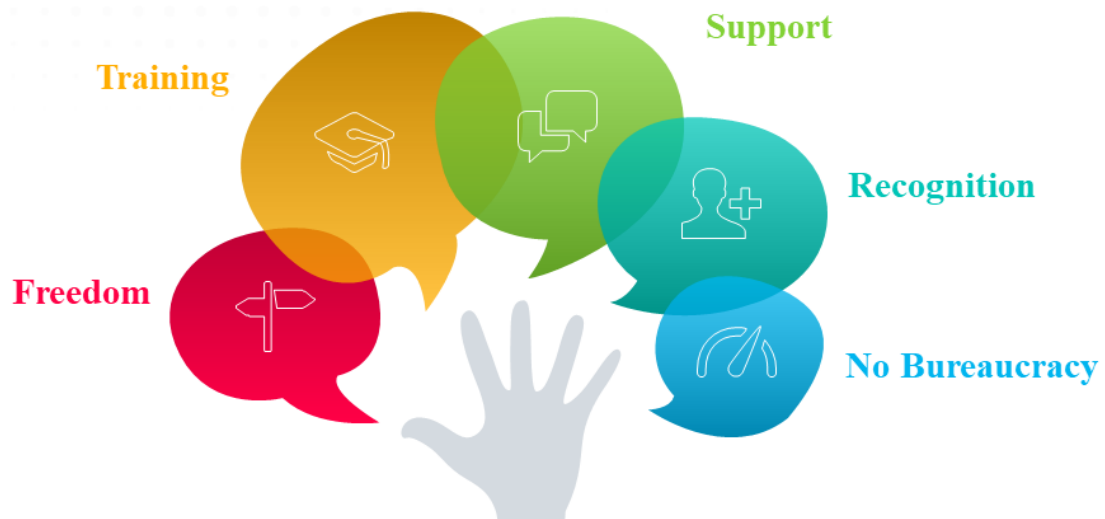

\section{Support Organization}

Figure 4. An efficient and satisfying volunteer requirement to be provided by support organization.

\section{A case study of volunteer education impact on so- ciety}

Education has, over time, impacted and transformed society and improved livelihoods. As in the case in Indonesia, volunteers can actively participate in politics and community development. Volunteers participated during and after elections and in running government programs [18]. Their activities can transform communities, and they have positively impacted lives are under-listed [19]:

1- It leads to sustainable community development: Education provides the most potent instruments for eradicating poverty, give a sense of conscience, and improve livelihoods. Education is an impetus to economic growth and breaking poverty cycles.

2- Education empowers women and minority groups in the community: It gives them knowledge of their civil rights and confidence to face issues of society.

3- It elevates tolerance levels and reduces conflicts among the diverse population in the society: Besides, it reduces violence and crime rate in the community.

4- Through education, society can learn from past mistakes: For example, they can learn from previous tribal clashes, bad governance, and dictatorship. The lessons from history are used to make future decisions.

5- Education gives hope for the future: It is a means of developing talents and abilities which can apply in the future.

\section{Volunteering educational research}

Overwhelmingly positive impacts of research and education in the community rely on the importance of profound comprehension of educational research. An analysis of data in a particular education field take two approaches:

1- The first approach is called a primary or academic research approach: This approach focuses on searching for truth and developing a theory. Its process is popular with undergraduate, graduate, and doctorate students who do it as part of university curriculum.

2- The other method is applied approach: It seeks to solve existing challenges in education. The outcome of this research directly influences practice. Its overall objective is to validate an educational theory or principle applicability and is achieved by hypothesis testing in specific settings. Author in [20] compared two approaches of the volunteerism nature, according to the table below.

Table 2: Comparative statement of ordinary and applied researches [20].

\begin{tabular}{lll}
\hline \hline No. Ordinary (Academic) Research & $\begin{array}{l}\text { Applied (Contract) Re- } \\
\text { search }\end{array}$ \\
\hline 1 & $\begin{array}{l}\text { An agency like a university or an } \\
\text { organization sponsors it just for } \\
\text { the advancement of knowledge. }\end{array}$ & $\begin{array}{l}\text { The agency funding re- } \\
\text { search has vested inter- } \\
\text { ests. }\end{array}$ \\
2 & $\begin{array}{l}\text { Expected outcomes of an investi- } \\
\text { gation or research belong to soci- } \\
\text { ety and community. }\end{array}$ & $\begin{array}{l}\text { The sponsor owns re- } \\
\text { sults and outcomes. }\end{array}$ \\
3 & $\begin{array}{l}\text { Researchers manage studies and } \\
\text { product depends on their reputa- } \\
\text { tion. }\end{array}$ & $\begin{array}{l}\text { The experiments comply } \\
\text { with the sponsor's terms } \\
\text { of reference to meet }\end{array}$
\end{tabular}


their interests and requirements.

4 The research targets other researchers in the same field.

The research targets a specific group of experts within bounded administrative and management plans.

5 Usually, regulated by theoretical- It is governed by predebased tests termined agreements and conventions between researchers and sponsors.

6 Focus on one set of testable hypotheses.

Analyzes the impact of alternative policy options.

7 Mostly focuses on a single scholarly discipline.

Often conduct interdisciplinary approaches.

8 Mostly ends with findings and con-Concludes with applied clusions. recommendations for taking action.

9 Sponsors and researchers' involve-Sponsor and rement rely on good faith. searcher's relationship depend on a contract.

10 Budgeting and accountability are Budgeting and accountaleft to researchers and depends on bility relate to contracglobal standards.

\section{Types of volunteers}

Throughout this study, the term volunteer or volunteering has appeared. Both of them apply to two types discussed below. A young volunteer can offer voluntary services in research and education in any of the categories listed below [21].

1- Informal volunteering: It is also called self-help and mutual aid. It is popular in society as a response to a community's needs. The activities practiced are not linked to any formal institution. For instance, if an adventure occurs in a community, people often respond quickly to extinguish.

2- Community volunteer: It refers to volunteers in a community sponsored by a formal institution, such as the university, organization, youth groups, and community groups.

3- National volunteer refers to a voluntary worker recruited by a formal body that operates on a national scale. These volunteers can work within their country or even abroad.

4- International volunteer: Refers to a volunteer who travels to another country specifically to offer voluntary services.

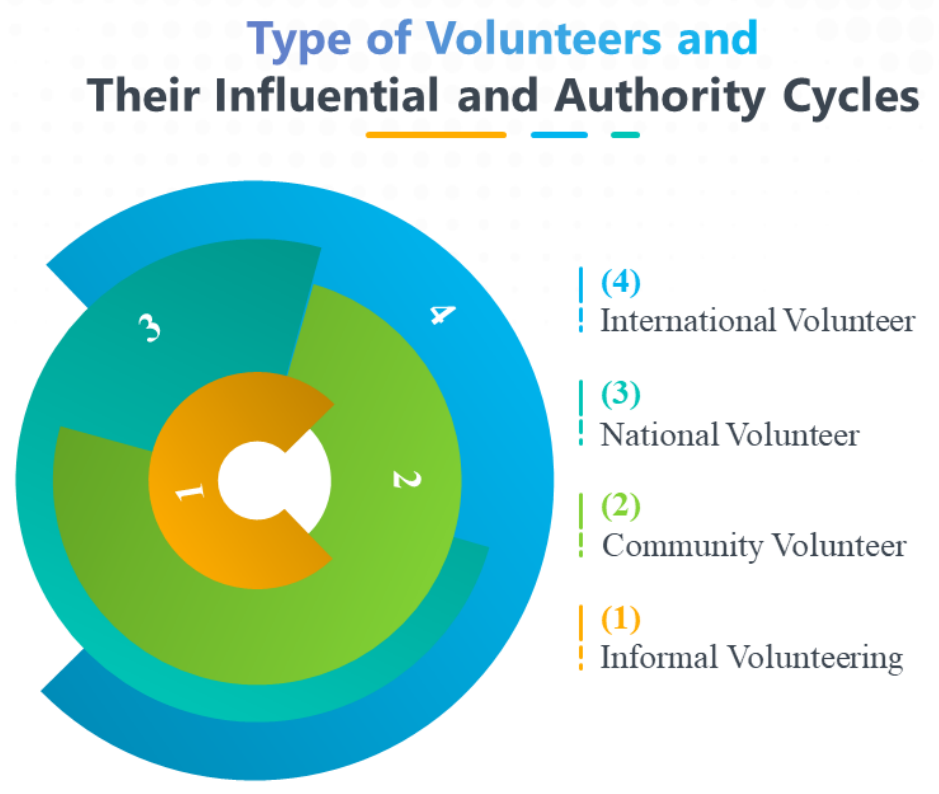

Figure 5. Type of volunteers and their influence and authority cycles.

\section{Value of volunteerism in the future of research and education}

Research involves people from all walks of life with different ages, academic levels, experiences, and personal backgrounds. As a result, research work is forever evolving to keep volunteers and students up to date. Therefore, by volunteering in the field of research and education, students contribute to shaping the future of education and daily technology development and innovations. With advancing technology and innovation in academia, examination assesses new learning options to optimize student 
experience and boost learning trends. Besides, notwithstanding the value it adds to education, this study prepares both tutors and students to handle real-life situations. With an increase in the number of students volunteering in research and education, the future will have healthier communities. The forthcoming of voluntary work depends on several parameters; statutory provisions, organizational structures of voluntary bodies, social workers, and researchers [22]. Recent studies on volunteerism updates and conceptual study with the current situation analysis are provided in [24].

\section{Characteristics of great volunteers}

Without a doubt, volunteering attracts impressive benefits. However, they are not the primary motivators to volunteer. Excellent volunteers are passionate about positively impacting and making the world a better place [23]. Below are common traits among them.

1- They are courageous: Volunteers have a fearless attitude to get out of comfort zones and meet the harsh realities of life. Experiencing new cultures, people, languages, traumatized and troubled people, and animals take courage.
2- They are patient: You may come in with a revolutionary idea, but it fails to materialize within schedule. Sometimes things drag or fall apart, but they keep moving on to achieve their objectives. They are persistent until they reach desired results.

3- They are keen to act out of self-initiative: Most times, voluntary work is voluminous, and it would be best if you did not have to wait for directions from your supervisors on every aspect. The experience creates a good work ethic that employers will need later.

4- They are passionate and desire to transform lives: Volunteering for college credit, boosting your CV, or hoping to change the opportunity into employment will not help make the most out of work.

5- They are team players: Most projects will be so big that they need a team. Excellent volunteers do not participate in fights and office politics. The art of teamwork is an asset to volunteering.

6- They are generally humble: Volunteers focus little on self and more on having a significant impact on others. Their selfless acts are what create an impact in the community.

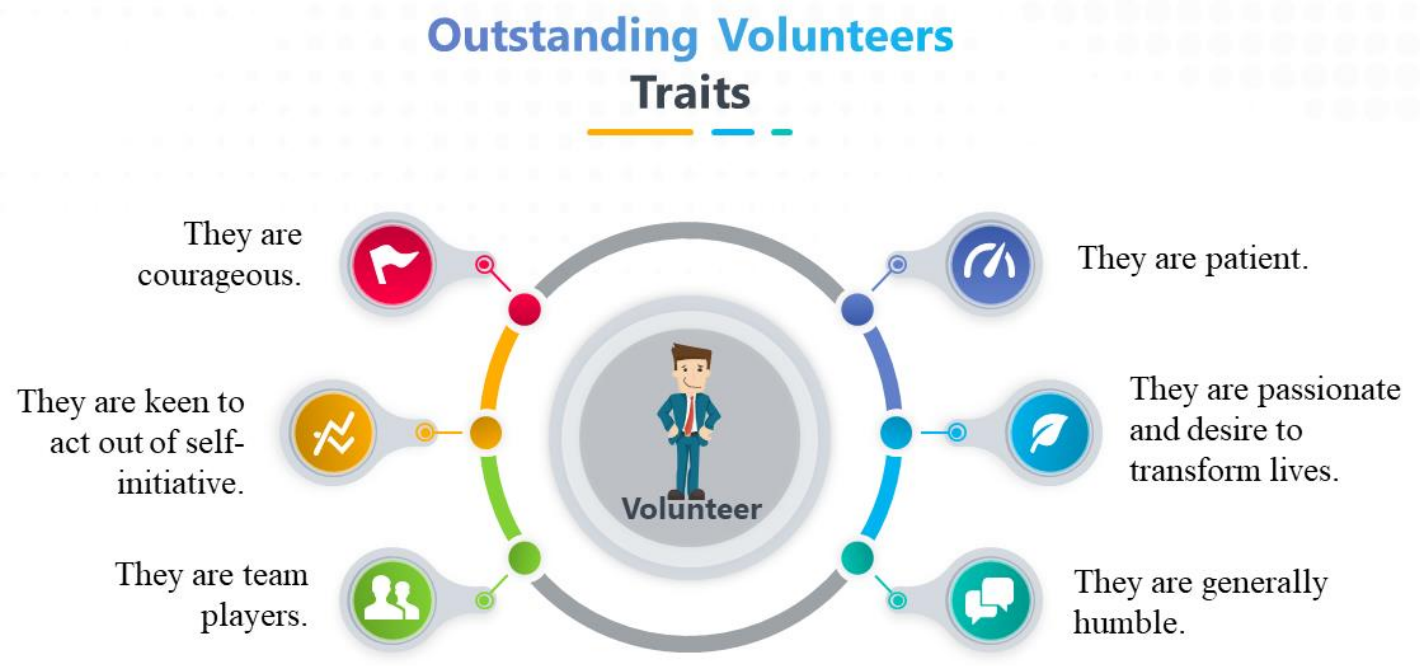

Figure 6. Outstanding volunteers' traits.

\section{Conclusion}

A young volunteer who comprehensively understands volunteerism nature and motivations for participating would most likely offer voluntary services in research and education during their studies. The study has met its objectives; students who study this paper will gain sufficient information to make an informed decision to start or continue volunteering. Listed advantages of offering voluntary services outweigh some disadvantages by far. Notwithstanding that sponsor organization has some objectives to achieve, both the young volunteer and community benefit substantially. Whereas some barriers to volunteering exist, most of them are due to misconceptions and lack of proper management. The opportunities to volunteer are enormous, and no student can excuse a lack of opportunity, including the research in education in universities, colleges, and research organizations. The 
possibilities range from local to international, and a student can select according to the occasion's convenience, preference, and availability. By participating in educational research, students get a chance to give back to society. The volunteerism nature grants a student an opportunity to shape a future career. Therefore, caution and diligence need to be given priority in the course of duty. Although research and education keep changing with time, we can conclude that future societies will be healthier by increasing voluntary work in research and education.

Based on the evidence, the best decision a student can make is volunteering in research and education within the mutual benefit of sponsor and volunteer. You have every reason to participate in voluntary work, go ahead, and execute.

\section{References (Different style)}

[1] Nathan C. Manual on volunteer services in public welfare. Washington: Dept. of Health Education, and Welfare, Social and Rehabilitation Service; 1972.

[2] Volunteering in the United States News Release [Internet]. Bls.gov. 2020 [cited 24 July 2020]. Available from: https://www.bls.gov/news.release/archives/volun_02252016.htm

[3] Bentson M. Volunteer Coordinator Handbook for Volunteer Programs Teaching Esl to Refugee Students. Tacoma Community House Training Project; 1983.

[4] Packham C. The Role of Youth and Community Work Training in Relation to Volunteers. 2008.

[5] Brennan M. Placing Volunteers at the Center of Community Development [Internet]. Semanticscholar.org. 2020 [cited 24 July 2020]. Available from: https://www.semanticscholar.org/paper/Placing-Volunteers-at-the-Center-ofCommunity-Brennan/9dce9cfdd3fac09e135aadb29cd4e9abd7806100

[6] Douglas P, Ryan T, Beller G, Hines E, Livingston D, McEntee $\mathrm{C}$ et al. Task Force 6: Code of Conduct for Staff and Volunteer Leadership. Circulation. 2004; 110 (16):2538-2549.

[7] ATLANTIS PRESS. Fostering Voluntarism in Digital Age [Internet]. 2019. Available from: https://download.atlantispress.com/proceedings/acec-19/125937433

[8] Hall-Ellis S, Grealy D. [Internet]. Pdfs.semanticscholar.org. 2013 [cited 24 July 2020]. Available from: ttps://pdfs.seman-

ticscholar.org/d41d/32a3239a7a4d43475e9744206787e 697bf59.pdf

[9] 5 Benefits of Performing Community Service in College [Internet]. Great Value Colleges. 2020 [cited 24 July 2020]. Available from: https://www.greatvaluecolleges.net/lists/5-benefits-of-performing-community-service-in-college/

[10] HuffPost is now a part of Verizon Media [Internet]. Huffpost.com. 2020 [cited 24 July 2020]. Available from: https://www.huffpost.com/entry/middle-school-gradesvolunteering_n_56293e48e4b0aac0b8fc3508
[11] Volunteering Produces Health Benefits - AmeriCorps Alums [Internet]. Americorpsalums.org. 2020 [cited 24 July 2020]. Available from: https://www.americorpsalums.org/page/LNVolunteerHealth

[12] Benefits of Community Service | Community Engagement [Internet]. Wcsu.edu. 2020 [cited 24 July 2020]. Available from: https://www.wcsu.edu/community-engagement/benefits-of-volunteering/

[13] How To Combat Barriers To Volunteering In 2019 [Internet]. Third Sector Protect. 2020 [cited 24 July 2020]. Available from: https://www.thirdsectorprotect.co.uk/blog/barriers-to-volunteering/

[14] Volunteer Opportunities for College Students [Internet]. Vault. 2020 [cited 24 July 2020]. Available from: https://www.vault.com/blogs/admit-one-vaults-mbalaw-school-and-college-blog/7-volunteer-opportunitiesfor-college-students

[15] Hunter E. Voluntarism, Virtuous Citizenship, and NationBuilding in Late Colonial and Early Postcolonial Tanzania. African Studies Review. 2015; 58 (2):48-49.

[16] The Impact of Research on Education on JSTOR [Internet]. Jstor.org. 2020 [cited 24 July 2020]. Available from: https://www.jstor.org/stable/20495397?readnow $=1 \&$ seq $=6 \#$ page_scan_tab_contents

[17] Active Involvement of Volunteers [Internet]. Uniteforsight.org. 2020 [cited 24 July 2020]. Available from: http://www.uniteforsight.org/effective-program-development/module8

[18] Suaedy A. The Role of Volunteers and Political Participation in the 2012 Jakarta Gubernatorial Election. Journal of Current Southeast Asian Affairs. 2014;33 (1):125-133.

[19] Project B. The Top 10 Effects Education Has on Society | The Borgen Project [Internet]. The Borgen Project. 2020 [cited 24 July 2020]. Available from: https://borgenproject.org/effectseducation-has-on-society/\#: :text=Education $\% 20$ leads $\% 20$ to $\% 20$ economic\%20prosperity,sold\%20on\%20the\%20open\%20market.

[20] Various Approaches for Educational Research | K12 Academics [Internet]. K12academics.com. 2020 [cited 24 July 2020]. Available from: https://www.k12academics.com/educationalresearch/approaches

[21] [Internet]. Vsointernational.org. 2020 [cited 24 July 2020]. Available from: https://www.vsointernational.org/sites/default/files/the_role_of_volunteering_in_sustainable_development_2015_vso_ids.pdf

[22] Morris M. Voluntary work in the welfare state. London: Routledge; 1998.

[23]Characteristics That Every Great Volunteer Has In Common [Internet]. AIESEC. 2020 [cited 24 July 2020]. Available from: https://www.aiesec.in/characteristics-every-greatvolunteer-common

[24] Kolnhofer Derecskei, A., \& Nagy, V. (2020). Employee Volunteerism-Conceptual Study and the Current Situation. Sustainability, 12(20), https://doi.org/10.3390/su12208378
8378. 